\title{
Baddeleyite, zircon and monazite minerals in the metasomatites of the Varena Iron Ore deposit in the western East European Craton: application for dating skarn and ore formation processes
}

\author{
G. SKRIDLAITE ${ }^{12 *}$, U. SÖDERLUND ${ }^{3}$, L. SILIAUSKAS ${ }^{1}$, T.
} NAERAA ${ }^{3}$

${ }^{1}$ Nature Research Centre, Vilnius, Lithuania

(*correspondence: grazina.skridlaite@gamtc.lt)

${ }^{2}$ Institute of Geosciences, Vilnius university, Lithuania

${ }^{3}$ Department of Geology, Lund university, Sweden (ulf.soderlund@geol.lu.se)

The Varena Iron Ore deposit in the Proterozoic basement of southern Lithuania, western East European Carton is situated predominantly in former dolostones along continental margin of ca. 1.84 Ga crust [1].

High-grade skarns (forsterite, enstatite, spinel and diopside) were produced during metamorphism at $750^{\circ} \mathrm{C}$ and 5-6 kbar, followed by fluid in-flux and amphibole (tremolite, actinolite, anthophyllite etc), phlogopite, magnetite, sulphide, apatite, zircon, monazite and baddeleyite mineralizations. Most of iron was introduced or remobilized at low temperatures (ca. $300-400^{\circ} \mathrm{C}$ ) together with serpentinization and iddingsite formation.

LA ICP-MS study was applied to the skarns in order to determine the age of mineralization. Sample 982-3 consists of thin, magnetite-rich and carbonate-dominated (with rounded serpentine and iddingsite grains) layers. Both baddeleyite and monazite yielded ages of approximately $1730 \mathrm{Ma}$. The D8-1 phlogopite-rich serpentinite is impregnated by magnetite and crosscut by magnetite, sulphide and carbonate veinlets. Irregular-shaped zircon grains intergrowing with magnetite produced somewhat ambiguous and scattered age results, with a main age group yielding ca. $1700 \mathrm{Ma}$.

The ore mineralization of ca. $1.73 \mathrm{Ga}$ is semi-simultinious with ca. 1.73 Ga metamorphic reworking in the neighbouring Lazdijai area and metamorphic overprint recorded by hornblende 40Ar/39Ar ages [2]. These events may be related to the TIB magmatism further west, across the Baltic Sea, in south-central Sweden.

[1] Bogdanova et al. (2015) Precambrian Research 259, 5-33. [2] Bogdanova et al. (2001), Tectonophysics 339, 3966. 